\title{
TRUMPETER SWANS BREEDING IN EAST-CENTRAL SASKATCHEWAN
}

\section{LEN SHANDRUK, DONALD F. HOOPER, and RHYS BEAULIEU.*}

The only recent documented location of Trumpeter Swans nesting in Saskatchewan has been the Cypress Hills. This flock peaked during the early 1970s when three pairs produced nine or ten signets. During 1991 one pair of Trumpeter Swans nested on Coulee Lake Reservoir and produced one cygnet. Neckbands put on the Cypress Hills swans by the Canadian Wildlife Service have indicated that they winter in the over-crowded Yellowstone/Tristate region. This may be one of the factors which has resulted in the very poor recruitment to this flock.

Over the last three to four years we have received reports of Trumpeter Swans in the area of Greenwater Provincial Park $\left(103^{\circ}\right.$ lat., $52^{\circ}$ long.) in east-central Saskatchewan. In October 1990, Donald Hooper and Herman Duerkson, local naturalists, observed and photographed a pair of adult swans and three cygnets on Greenwater Lake. From the call of this pair and inspection of the photos it was concluded that this was indeed a pair of Trumpeter Swans.

Greenwater Lake, Saskatchewan, is far from any of the known Trumpeter Swan breeding areas in western Canada. The closest known breeding site is at Elinor Lake in northeastern Alberta and Cypress Hilis in southwestern Saskatchewan. Other areas which are just as close are Lacreek National Wildlife Refuge in South Dakota and Delta Waterfowl Research Station in Manitoba.

While conducting fire surveys by helicopter during the spring of 1991 Rhys Beaulieu, wildlife ecologist with the Saskatchewan Wildlife Branch, noticed a pair of swans nesting on a small lake in the northern portion of Greenwater Lake Provincial Park. During a subsequent survey, he and park officials observed the pair with one cygnet. During early July the pair abandoned the breeding lake for another lake several kilometres to the northeast of the breeding sites, minus the cygnet.

On the invitation of the Saskatchewan Wildlife Branch, Len Shandruk of ithe Canadian Wildlife Service in Edmonton travelled to Greenwater Lake on 23 July 1991 to capture, identify and mark the pair of swans. With the assistance of Rhys Beaulieu, Don Hooper and park officer T.P. Andrychuk, we captured this moulting flightless pair using a motorboat and salmon-landing net. While they were being captured, the pair vocalized and their calls were recognized as that of trumpeters. The

* LEN SHANDRUK, Canadian Wildlife Service, Environment Canada, Room 210, 4999-98 Avenue, Edmonton, Alberta, T6B 2X3; DONALD F. HOOPER, Box 40, Somme, Saskatchewan, SOE 1NO; and RHYS BEAULIEU, Saskatchewan Parks and Renewable Resources, Wildlife Branch, Box 970, Hudson Bay, Saskatchewan SOE OYO 


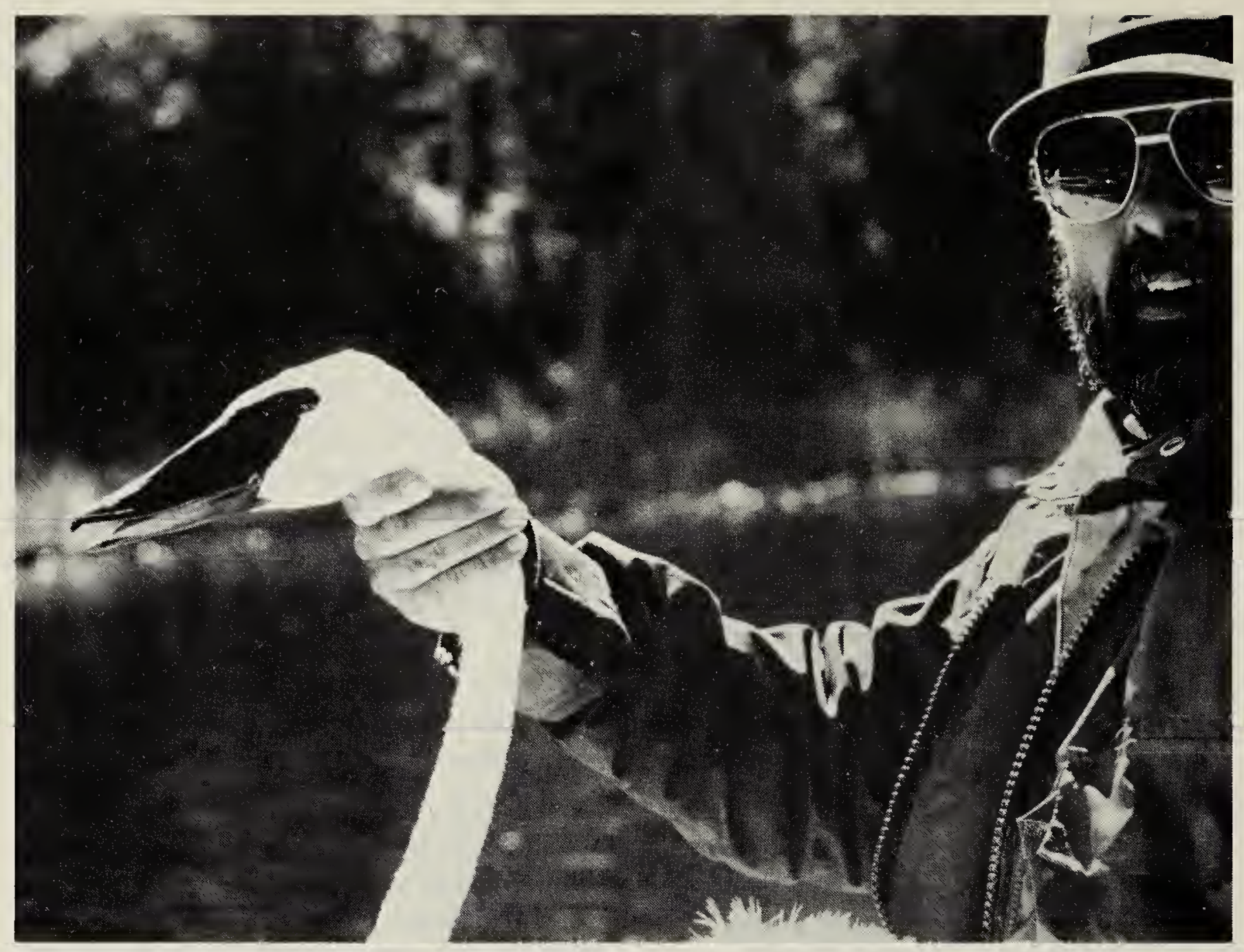

Len Shandruk with captured Trumpeter Swan

Donald F. Hooper

pair was leg-banded, collared, weighed, measured, and given parasite control medication. Samples of their blood were taken. The weights and measurements collected were determined to be in the range of the Trumpeter Swan and far exceeded those of the Tundra or Whistling Swan. The male received a yellow collar, $30 \mathrm{AC}$, while the female got yellow, $31 \mathrm{AC}$. Both birds were just starting to grow new primaries. The new wings were just over $100 \mathrm{~mm}$ long.

A search of the breeding lake located the nest site, with some shell fragments and one dead cygnet which had died just prior to or during hatching. The nest was in shallow water cattail habitat about $65 \mathrm{~m}$ from shore. It was built up with cattails and other aquatic vegetation about $40 \mathrm{~cm}$ above the mucky bottom with a wide moat around it.

The last recorded observation of this collared pair in Canada was on $13 \mathrm{Au}$ gust 1991 when they were observed on a lake about one $\mathrm{km}$ west of the cap- ture site. Later, on 30 October 1991, a call was received by the Canadian Wildlife Service from Jay Pederson, assistant refuge manager of the Lacreek National Wildlife Refuge near Martin, South Dakota. He informed us that two yellow-collared swans ( 30 and $31 \mathrm{AC}$ ) were observed wintering on the refuge. This was very exciting news as it was the first time in recent history that Trumpeter Swans breeding in Canada were discovered using a new flyway and wintering area. This discovery could lead to management activities (sanctioned by the Rocky Mountain Population Recovery Plan and the Trumpeter Swan Society) that would increase the size of the flock breeding in Saskatchewan and wintering in an area other than the over-crowded Tristate region.

Should anyone observe these Trumpeter Swans again, we would appreciate being contacted with details of their location. 